\title{
Factors Contributing to the Development of E-Commerce by the Degree of use in Latvia
}

\section{Ina Gudele}

Latvia University of Life Sciences and Technologies

\section{Inga Jekabsone}

RISEBA University of Applied Sciences

\section{EIS $14 / 2020$}

Factors Contributing to the Development of E-Commerce by the Degree of use in Latvia

Submitted 05/2020

Accepted for publication $07 / 2020$

\section{Abstract}

Purpose of the study is to analyse the factors contributing to the development of the e-commerce in Latvia by the degree of use of e-commerce.

The tasks of the study:

1 to review theoretical background of factors contributing to the development of the e-commerce depending on the degree of use of e-commerce in the enterprise;

2 to review existing research of factors contribution to the development of the e-commerce in EU;

3 to analyse the results of conducted survey among Latvian entrepreneurs in context of factors contributing to the development of the e-commerce.

Research methods used in preparation of the paper: scientific publication and previous conducted research results analysis, analysis of the results of the survey on Latvian entrepreneurs. Survey results are analysed using indicators of descriptive statistics (indicators of central tendency or location - arithmetic mean, mode, median), indicators of variability (indicators of dispersion - range, standard deviation and standard error of mean), analysis of variance - ANOVA are used.

The survey showed that there are significant differences in the assessment of the groups of factors "Social factors" and "Regulatory factors" between entrepreneurs who take full advantage of e-commerce opportunities and those who do not use them at all. In order to promote the use of e-commerce possibilities, different trainings and programmes should be developed to improve the knowledge, skills and competences of employers and employees in the area of e-commerce.

KEYWORDS: e-commerce, factors, entrepreneurs, Latvia.

In the early 1990s, a new term appeared around the world - electronic commerce. E-commerce has completely changed the traditions of business operations and development, enabling sales, buying, offering and receiving, providing information and providing support remotely.

There are ongoing studies on factors that promote the development of e-commerce (e.g. Abdullah et al., 2019; Gajewska and Zimon, 2018; Martinez-Lopez et al., 2015; Yoon and Occena, 2015). Mostly, the factors that influence the development of e-commerce are divided in such categories: technological factors, social factors, economic factors, political factors and psychological factors (see more Viehland, 2000; Shah Alam et al., 2011; Makki and Chang, 2015; Kabango and Asa, 2015).

Introduction

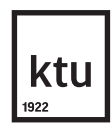

European Integration Studies No. 14 / 2020, pp. 207-216 doi.org/10.5755/j01.eis.1.14.26385 
Regarding the development of e-commerce in Latvia, Latvia as a whole ranks $17^{\text {th }}$ among $28 \mathrm{EU}$ Member States according to the Digital Economy and Society Index (DESI) for 2019 results, with the level of digitization slightly below the EU average. Evaluating Latvia's performance since 2014, Latvia has made significant progress in the area of digital public services, as well as in the connectivity dimension. However, the level of digital skills of the population is low, as is the use of digital technologies in enterprises. According to the recent data, only 5\% of SME turnover comes from online segment (24 $4^{\text {th }}$ among 28 EU Member States) (European Commission, 2019). Thereby, the it is important to analyse the factors contributing to the development of e-commerce from the perspective of the enterprises that do not use the e-commerce possibilities.

Taking into account all mentioned before, the purpose of the study is to analyse the factors contributing to the development of the e-commerce in Latvia by the degree of use of e-commerce.

In order to achieve the purpose, the tasks are formulated as follows:

1 to review theoretical background of factors contributing to the development of the e-commerce depending on the degree of use of e-commerce in the enterprise;

2 to review existing research of factors contribution to the development of the e-commerce in EU;

3 to analyse the results of conducted survey among Latvian entrepreneurs in context of factors contributing to the development of the e-commerce.

Research methods used in preparation of the paper: scientific publication and previous conducted research results analysis, analysis of the results of the survey on Latvian entrepreneurs. Survey results are analysed using indicators of descriptive statistics (indicators of central tendency or location - arithmetic mean, mode, median), indicators of variability (indicators of dispersion - range, standard deviation and standard error of mean), analysis of variance - ANOVA are used.

Factors contributing to the development of e-commerce: theoretical framework
Several authors in their publications compare the development of e-commerce and digital environment in developed and developing countries mention the factors that contribute to the development of e-commerce (such as Choshin and Ghaffari, 2017; Sebora et al., 2009). With the development of technology, communication network infrastructure diminishes its importance as mobile communications evolve, which are much cheaper and allow the digital environment to be used with all its services using only mobile phones, which to some extent replace computers. The use of infrastructure and the equipment itself is becoming cheaper. Sridhar and Sridhar (2006) propose to determine the level of development of e-commerce in developed countries according to the development of telecommunications infrastructure, divided into several sub-sections, which allows to determine the level of development of the same factor as population using the Internet, quality of Internet services (data rate), also taking into account the data security aspect, regulation, payment methods on the Internet and cultural characteristics, user behaviour. Kalinic et al. (2016), analysing the factors influencing e-commerce in Serbia, where historically technology and economy developed similarly to Latvia, also emphasizes the influence of the same four main factors on e-commerce development (technological, political, economic and educational factors), the situation was largely similar from both from the point of view of users and enterprises. In addition to the above-mentioned factors, Wang and Liu (2015) mention another important factor - the cultural factor, which significantly influences both the development of the digital environment itself and the use of this environment from the users' point of view.

The development of the digital environment and e-commerce also leads to the formation of other influencing factors, such as the trust of cooperation partners in each other, openness, access opportunities, trust (Kabango and Asa, 2015). 
In turn, authors such as Zaied (2012), who studied barriers to the development of e-commerce, divided them into six categories: economic barriers, regulation, organisational barriers, social and cultural barriers, technical problems.

Wang and Liu (2015) propose to analyse a total of 12 factors influencing the digital environment and e-commerce, including development, adding to all of the above a group with social factors such as standard of living, human capital and price index, urbanization level and diffusion of technology.

The results of the scientific literature review are illustrated in Fig. 1.

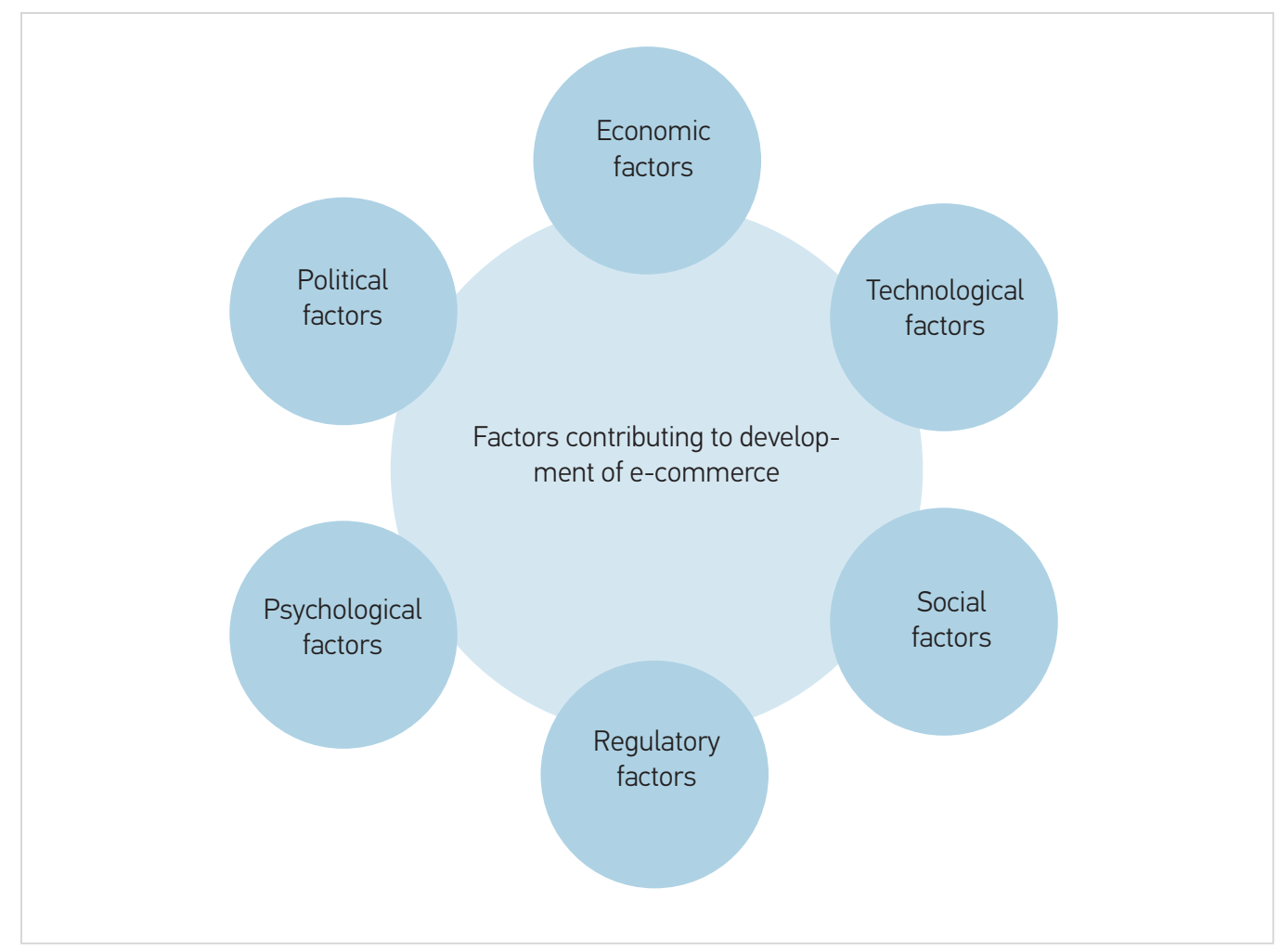

All the findings of these authors' studies on the factors influencing the level of development of the digital environment and e-commerce do not differ significantly from country to country or region. Their main meaning and impact are equal, only the level of detail of the influencing factor differs. In each country, one or the other factor is more or less weighty.

In order to analyse the factors contributing to the development of e-commerce in Latvia, a survey for entrepreneurs was developed. The aim of the survey was to find out what factors influence the use of e-commerce in Latvian enterprises, incl. how these factors differ depending on the intensity of e-commerce use. The survey was conducted from November 2019 to January 2020. The survey was distributed using the contact channels of Latvian Internet Association and Latvian Chamber of Commerce and Industry (in total more than 500 enterprises were asked to fill the survey). In total, 77 enterprises representing all regions of Latvia, as well as various sectors of the national economy, participated in the survey. Taking into account significant number of SME ${ }^{1}$

\section{Figure 1}

Factors contributing to the development of e-commerce: summary of scientific literature study (Abdullah et al., 2019; Gajewska and Zimon, 2018; Martinez-Lopez et al., 2015; Wang and Liu, 2015)

\section{Empirical research results}




\section{Figure 2}

Answers to the question "Does your enterprise take full advantage of e-commerce opportunities to grow your business?"

\section{Figure 3}

Answers to the question "Please rank the groups of impact factors in order of importance (1 is the most important) that most influence e-commerce development - by the degree of use of e-commerce in Latvia, the sample is rather small. However, the enterprises represent different economic sectors, regions and economic outcomes, so the results of the survey could be analysed to provide an impression on SME sector of Latvia.

Overall, the majority (57\%) of the surveyed enterprises partially use e-commerce opportunities, a quarter of enterprises admitted that they make full use of e-commerce opportunities. In turn, $14 \%$ of enterprises admitted that they do not use e-commerce opportunities (see Fig.2). It should be mentioned that in order to avoid the subjectivity, in the survey the explanation was provided to answers "Fully used" and "Partly used". "Fully used" means that enterprise fulfils all three criteria: sales goods and services on Internet, promotes goods and services on Internet and communicates with clients on Internet. "Used partly" means that enterprise fulfils only one or two criteria mentioned above.

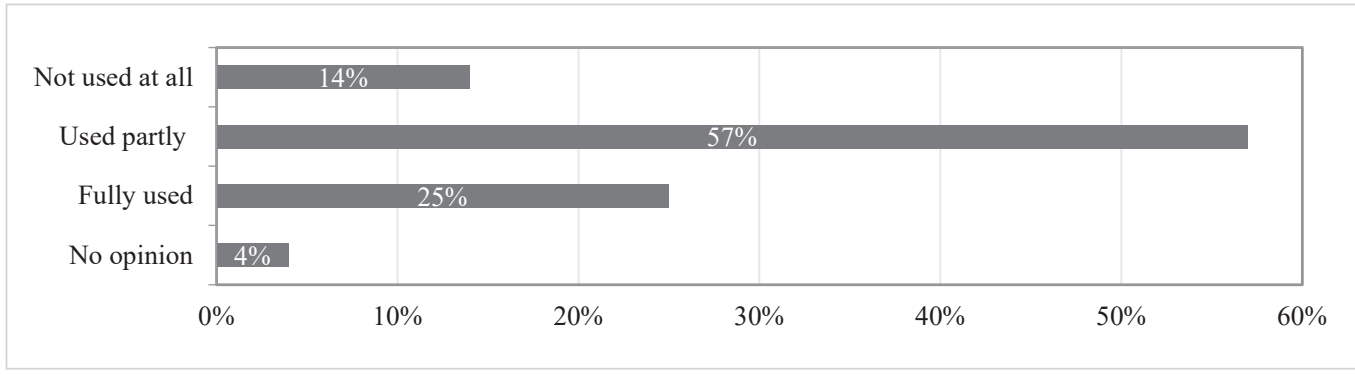

Source: Authors' conducted survey, number of respondents - 77; research period: November 2019 - January 2020

Further analysis is on assessment of the importance of groups of e-commerce factors between enterprises that do not use e-commerce at all and those that take full advantage of e-commerce (see Fig. 3). This selection was done in order to find the differences in evaluation of factors from the perspective of the use of e-commerce in the enterprises.

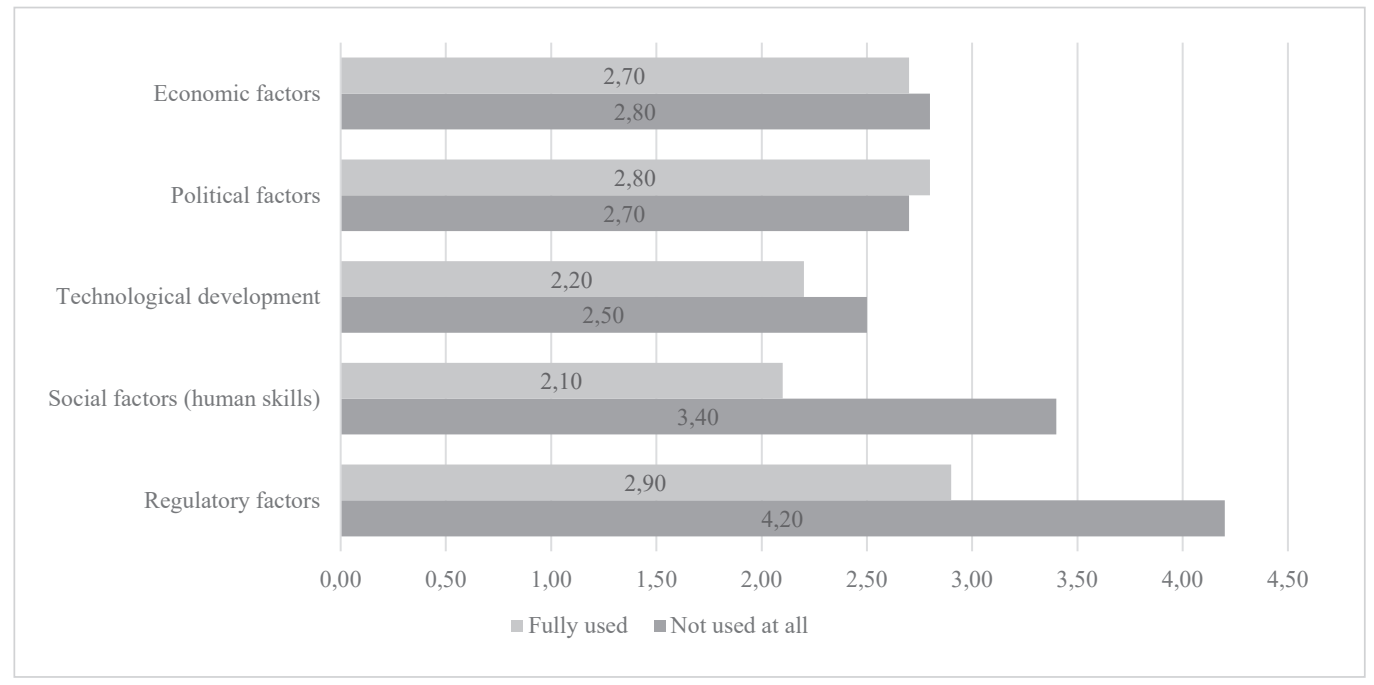

Source: Authors' conducted survey, number of respondents - 30; research period: November 2019 - January 2020

The initial comparison between entrepreneurs who take full advantage of e-commerce opportunities and those who do not use them at all differs in their assessment of the most important groups of factors influencing the development of e-commerce. As can be seen in Fig.3, the assessment of the factor groups "Social Factors" and "Regulatory factors" is quite different, i.e. 
entrepreneurs who do not use e-commerce opportunities at all, their assessments of the factor groups "Social Factors" and "Regulatory factors" rated as less important in the development of e-commerce compared to entrepreneurs who take full advantage of e-commerce opportunities.

To determine whether there are significant differences in the assessments between enterprises who take full advantage of e-commerce opportunities and those who do not use e-commerce rights at all, an F-test was performed to see if there was a significant variation between these samples. The calculations showed that in all cases the value of $F$ was lower than the critical value of $F$. This means that the null hypothesis of equal variations in both samples cannot be rejected at the significance level $a=0.05$ and the variations in both samples (entrepreneurs who do not use e-commerce at all and entrepreneurs who take full advantage of e-commerce) are the same.

The $t$ test was then performed on the averages of both samples, i.e. the null hypothesis ( $\mathrm{Ho}$ ) was put forward that the averages of both samples (entrepreneurs who do not use e-commerce opportunities at all and entrepreneurs who make full use of e-commerce opportunities) for each group of factors are equal at a significant level $a=0.05$. The calculation showed (see Table 1 ) that the statistical value of thas been higher than the critical value of $t$ at the significance level $a=0.05$ for such groups of factors as "Social factors" and "Regulatory factors". This means that the null hypothesis has to be rejected and there are significant differences between the means of the two samples. Therefore, it must be concluded that there are significant differences in the assessment of the groups of factors "Social factors" and "Regulatory factors" that affect the development of e-commerce, between entrepreneurs who take full advantage of e-commerce opportunities and those who do not use them at all.

In other cases (factor groups "Economic factors", "Political factors" and "Technological factors") there are no differences between the importance of factors in the development of e-commerce between enterprises that do not use e-commerce opportunities at all and those that use e-commerce opportunities fully.

\begin{tabular}{l|c|c|c}
\multicolumn{1}{c|}{ Group of factors } & t statistical value & $\mathrm{t}$ critical value & Result \\
\hline Economic factors & 0,135 & 2,055 & Ho cannnot be rejected \\
\hline Political factors & 0,236 & 2,055 & Ho cannnot be rejected \\
\hline Technological factors & 0,416 & 2,048 & Ho cannnot be rejected \\
\hline Social factors & 2,446 & 2,051 & Ho rejected \\
\hline Regulatopry factors & 2,766 & 2,051 & Ho recected \\
\hline
\end{tabular}

Source: Authors ' conducted survey, number of respondents - 30; research period: November 2019 - January 2020

Next, an analysis was made as to whether there are differences between specific factors between entrepreneurs who make full use of e-commerce opportunities and those who do not use them at all (see Fig. 4).

An initial comparison shows that the average score for each factor differs the most for factors such as "Leader in the country" (the difference in the average score between entrepreneurs who do not use e-commerce at all and those who take full advantage of e-commerce is 56\%).), "Leader of NGO" (difference - 53\%), "Leader in the municipality" (39\%), "Competitor activity" (37\%), "NGO activity" (36\%) and "Positive success stories" (32\%). On the other hand for the factors "Managerial knowledge", "Existence of financial resources in the company", "State support" and "Business environment in the country" the difference in assessments in average between entrepreneurs who do not use e-commerce opportunities and those who fully use e-commerce opportunities, is below $10 \%$.
Table 1

t- Results of $t$-Test Two-Sample Assuming Equal Variances (group of factors) by the degree of use of e-commerce 


\section{Figure 4}

Answers to the question "Please rate on a scale of 1 (not significant) to 9 (very important), (10-no opinion) factors that you think affect the use of e-commerce in your business" - by the degree of use of e-commerce

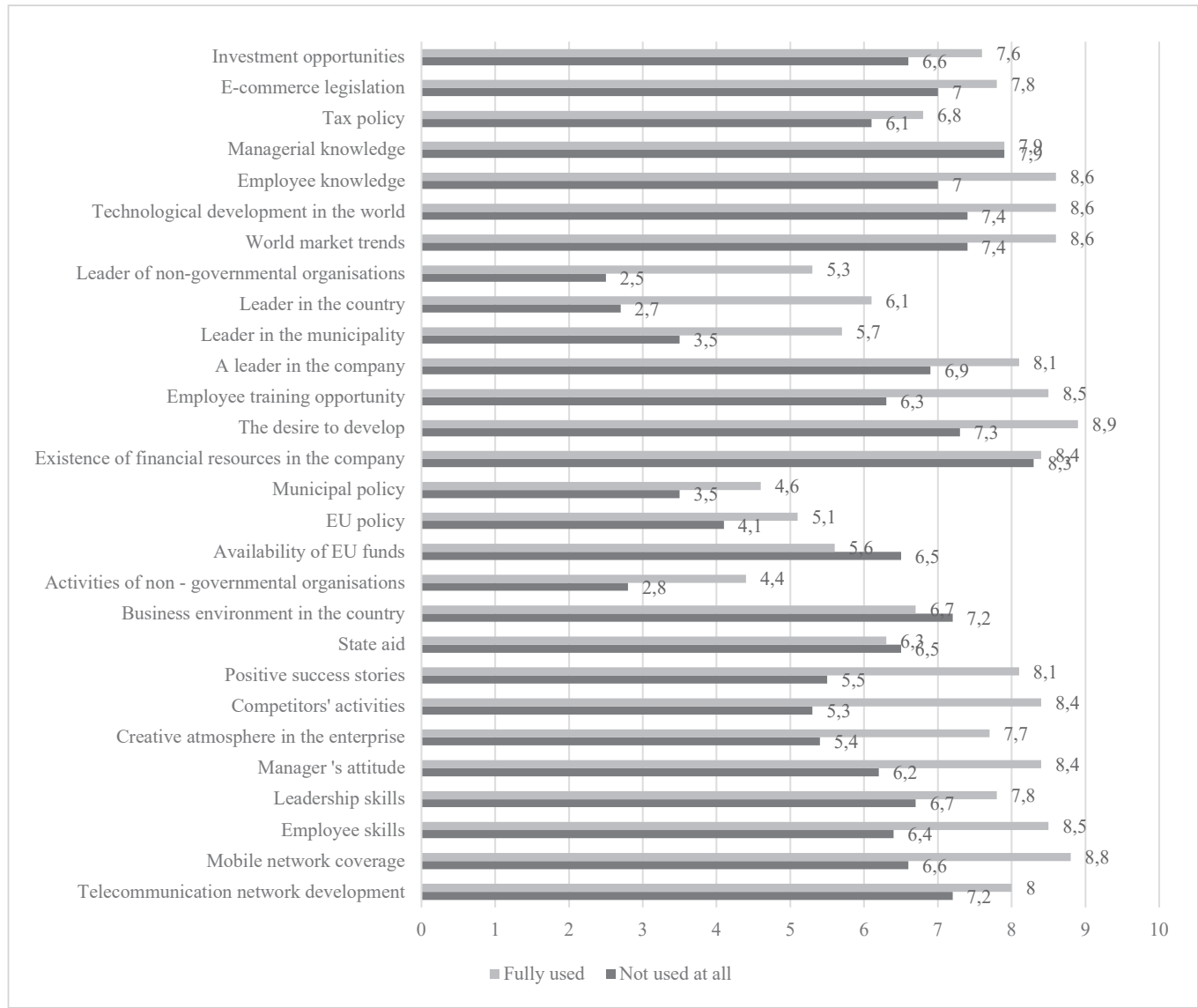

Source: Authors' conducted survey, number of respondents - 30; research period: November 2019 - January 2020

However, in order to find out whether there are significant differences enterprises' assessment of the factors influencing the development of e-commerce, depending on whether they make full use of e-commerce or not at all, an F-test for sample variations was initially performed. Its results showed that in all cases the value of $F$ was below the critical value of $F$. This means that the null hypothesis of equal variations in both samples cannot be rejected at the significance level a $=0.05$ and the variations in both samples (entrepreneurs who do not use e-commerce at all and entrepreneurs who take full advantage of e-commerce) are the same.

The $t$ test was then performed on the averages of both samples, i.e. the null hypothesis ( $\mathrm{Ho})$ was put forward that the averages of both samples (entrepreneurs who do not use e-commerce opportunities at all and entrepreneurs who make full use of e-commerce opportunities) for each factor are equally at the significance level $a=0.05$.

$\mathrm{t}$ test calculations are shown in Table 2. Comparing the statistical values of $\mathrm{t}$ with the critical values of $\mathrm{t}$, it must be concluded that the null hypothesis $(\mathrm{Ho})$ about the average equality of both samples must be rejected at the significance level $a=0.05$ for the following factors:

- Mobile network coverage; _ Competitors' activities;

- Employee skills;

- Manager's attitude;

- Creative atmosphere in the company;
- Positive success stories;

- Desire to develop;

- Employee training opportunity;

- Leader in the country;
- Leader of non-governmental organisations;

- Global market trends;

- Technological development in the world;

- Employee knowledge. 


\begin{tabular}{|c|c|c|c|}
\hline Factor & t statistical value & t critical value & Result \\
\hline Telecommunication network development & 0,960 & 2,048 & Ho cannnot be rejected \\
\hline Mobile network coverage & 3,159 & 2,048 & Ho rejected \\
\hline Employee skills & 2,591 & 2,048 & Ho rejected \\
\hline Leadership skills & 1,265 & 2,048 & Ho cannnot be rejected \\
\hline Manager 's attitude & 2,429 & 2,048 & Ho rejected \\
\hline Creative atmosphere in the enterprise & 2,570 & 2,048 & Ho rejected \\
\hline Competitors' activities & 4,148 & 2,048 & Ho rejected \\
\hline Positive success stories & 3,749 & 2,048 & Ho rejected \\
\hline State aid & 0,304 & 2,051 & Ho cannnot be rejected \\
\hline Business environment in the country & 0,746 & 2,048 & Ho cannnot be rejected \\
\hline Activities of non - governmental organisations & 1,343 & 2,051 & Ho cannnot be rejected \\
\hline Availability of EU funds & 0,746 & 2,048 & Ho cannnot be rejected \\
\hline EU policy & 0,836 & 2,048 & Ho cannnot be rejected \\
\hline Municipal policy & 0,839 & 2,051 & Ho cannnot be rejected \\
\hline $\begin{array}{l}\text { Existence of financial resources in the } \\
\text { company }\end{array}$ & 0,234 & 2,048 & Ho cannnot be rejected \\
\hline The desire to develop & 2,925 & 2,048 & Ho rejected \\
\hline Employee training opportunity & 3,415 & 2,048 & Ho rejected \\
\hline A leader in the company & 1,428 & 2,048 & Ho cannnot be rejected \\
\hline Leader in the municipality & 1,801 & 2,048 & Ho cannnot be rejected \\
\hline Leader in the country & 3,166 & 2,048 & Ho rejected \\
\hline Leader of non-governmental organisations & 2,342 & 2,048 & Ho rejected \\
\hline World market trends & 3,142 & 2,048 & Ho rejected \\
\hline Technological development in the world & 2,836 & 2,048 & Ho rejected \\
\hline Employee knowledge & 2,786 & 2,048 & Ho rejected \\
\hline Managerial knowledge & 0,007 & 2,051 & Ho cannnot be rejected \\
\hline Tax policy & 0,604 & 2,051 & Ho cannnot be rejected \\
\hline E-commerce legislation & 0,962 & 2,048 & Ho cannnot be rejected \\
\hline Investment opportunities & 0,157 & 2,048 & Ho cannnot be rejected \\
\hline
\end{tabular}

Source: Authors' conducted survey, number of respondents - 30; research period: November 2019 - January 2020 
This means that the average assessment of these factors differs significantly between enterprises that do not use e-commerce opportunities at all and those that do not. In other cases, factors related to telecommunications network development, managerial skills, state aid, the average score does not differ significantly between enterprises that take full advantage of e-commerce and those that do not use e-commerce at all.

Based on an analysis of the results obtained, the authors provide specific recommendations for the development of the digital environment stakeholders, with an increased focus on factors that have a positive impact on the development of e-commerce in business development and economic strengthening:

- National authorities, in cooperation with non-governmental business organisations, should become contracting educational institutions, which should develop a variety of vocational training, lifelong learning and non-formal education training programmes for business leaders and employees, by increasing their competence in the practical use of the digital environment for business development, including the use of e-commerce.

- Municipalities, in cooperation with non-governmental business organisations, can step up the best examples of e-commerce in business development and export promotion, involving central and local media. This will provide a positive example and an initiative for other entrepreneurs to transform their business into a digital environment.

- National authorities, in cooperation with local governments should continue the course launched on the development of broadband infrastructure, providing high-quality infrastructure in areas where data transmission coverage has not yet been provided with the quality required for the use of e-commerce for business purposes. It will also make a significant contribution to regional development by giving a signal to entrepreneurs about the availability of adequate digital infrastructure in remote regions, creating companies or branches there.

- A study and data analysis by the authors show that the potential of e-commerce in Latvia is greater than the use of existing opportunities. The factors defined by many authors show that the environment leading to the successful use of e-commerce for business development. It has threatened that, through a complex engagement with the more empowered parties company management, public authorities, local governments, educational institutions and non-governmental organisations have the potential to successfully develop digital transformation in companies by promoting the use of e-commerce for economic growth.

- Overall, the majority (57\%) of the surveyed enterprises partially use e-commerce opportunities, a quarter of enterprises admitted that they make full use of e-commerce opportunities. In turn, $14 \%$ of enterprises admitted that they do not use e-commerce opportunities. This shows that entrepreneurs in Latvia are at different stages of development in the use of e-commerce opportunities, thus training and informing entrepreneurs about the use of e-commerce opportunities is topical, especially in the regions of Latvia (Kurzeme and Latgale).

- At the same time, when analysing the importance of different groups of e-commerce factors depending on how intensively entrepreneurs use e-commerce opportunities, there are significant differences in the assessment of factor groups "Social factors" and "Regulatory factors" between entrepreneurs who make full use of e-commerce opportunities and those who do not use them at all. Those who do not take advantage of e-commerce at all consider the factor groups "Social factors" and "Regulatory factors" to be less important than those who take full advantage of e-commerce. This shows that regulation and human skills are a major obstacle to achieving a higher level of e-commerce use. 
- On the other hand, analysing the impact of individual factors on the development of e-commerce, depending on the intensity of use of e-commerce opportunities, it must be concluded that there are significant differences in the assessment of factors. Enterprises that take full advantage of e-commerce consider following factors to be very important in the development of e-commerce: mobile network coverage, employee skills, managerial attitude, creative atmosphere in the company, competitors' activities, positive success stories, desire to develop, employee training opportunity, a leader in the country, a leader of non-governmental organizations, market trends in the world, technological development in the world, employee knowledge. Thus, in general, those who have more knowledge, skills and competencies in the use of e-commerce, on the one hand, also give a higher assessment of the factors influencing the development of e-commerce, on the other hand, highly value the factors that belong to groups of factors. Social factors (e.g. desire to develop, employee knowledge, employee training opportunities) and "Technological factors" (e.g. mobile network coverage, technological development in the world).

- It is clear that "Technological factors", which include data transfer infrastructure in Latvia, are developed at a good level, so respondents do not regard it as a disruptive factor for e-commerce, while it is highly relevant to the "competitor activities" factor, which shows that when they see the growth of other competing companies or the positive experience of similar companies using digital experience. technology in the development of its business could give a positive impact to the management of the company, which is considered to be a highly impacting factor, to focus on the uptake of e-commerce in its activities.

Abdullah, L., Ramli, R. Bakodah, H.O. Othman, M. (2019). Developing a causal relationship among factors of e-commerce: A decision making approach. Journal of King Saud University - Computer and Information Sciences, 1-9. https://doi.org/10.1016/j. jksuci.2019.01.002

Choshin, M., Ghaffari,A. (2017). An investigation of the impact of effective factors on the success of e-commerce in small- and medium-sized companies. Computers in Human Behaviour, 66, 67-74. https://doi.org/10.1016/j.chb.2016.09.026

European Commission (2019). SESI Country Report: Latvia. Retrieved May 27, 2020, from: https:// ec.europa.eu/newsroom/dae/document.cfm?doc_ $i d=59899$

Gajewska, T., Zimon, D. (2018). Study of the logistics factors that influence the development of e-commerce services in the customer's opinion. Archives of Transport, 45 (1), 25-34. https://doi. org/10.5604/01.3001.0012.0939

Kabango, C.M., Asa, A.R. (2015). Factors influencing e-commerce development: implications for the developing countries. International Journal of Innovation and Economic Development, 1 (1), 59-66. https://doi. org/10.18775/ijied.1849-7551-7020.2015.11.2006

Kalinic, Z., Rankovic, V., Kalinic, L. (2016). Factors influencing e-commerce development in Serbia. Facta Universitatis: Economics and Organisation, 13(3), 287-300.

Makki, E., Chang, L. (2015). E-commerce acceptance and implementation in Saudi Arabia: previous, current and future factors. International Journal of Management Research and Business Strategy, 4 (3), 29-44.

Martinez-Lopez, F.J., Esteban-Millat, I., Cabal, C.C., Gengler, C. (2015). Psychological factors explaining consumer adoption of an e-vendor's recommender. Industrial Management \& Data Systems, 115 (2), 284310. https://doi.org/10.1108/IMDS-10-2014-0306

Sebora, T.C., Lee, S.M., Sukasame, N. (2009). Critical success factors for e-commerce Entrepreneurship: An Empirical Study of Thailand. Small Business Economic, 32 (3), 303-316. https://doi.org/10.1007/ s11187-007-9091-9

Shah Alam, S., Ali, M.Y., Mohd Jani, M.F. (2011). An empirical study of factors affecting electronic com- 
merce adoption among SMEs in Malaysia. Journal of Business, Economics and Management, 12 (2), 375399. https://doi.org/10.3846/16111699.2011.576749

Sridhar, V., Sridhar, V. (2006). E-commerce infrastructure and economic impacts in countries: case of India. In Sherif, K. (Ed.), Electronic business in developing countries: opportunities and challenges (pp. 63-87). Hershey, PA: Idea. https://doi. org/10.4018/978-1-59140-354-8.ch004

Viehland, D.W. (2000). Critical success factors for developing an e-business strategy. Proceedings of 6th Americas Conference on Informatics Systems, 13, 911-915.
Wang, X., Liu, L. (2015). Empirical research on the influence factors of e-commerce development in China. The Open Cybernetics \& Systemics Journal, 9(1), 7682. https://doi.org/10.2174/1874110X01509010076

Yoon, H.S., Occena, L.S. (2015). Influencing factors of trust in consumer-to-consumer electronic commerce with gender and age. International Journal of Information Management, 35 (3), 352-363. https:// doi.org/10.1016/j.ijinfomgt.2015.02.003

Zaied, A. (2012). Barriers to e-commerce adoption in Egyptian SMEs. International Journal of Information Engineering and Electronic Business, 3, 9-18. https://doi.org/10.5815/ijieeb.2012.03.02

The research was supported by the NATIONAL RESEARCH PROGRAMME "LATVIAN HERITAGE AND FUTURE CHALLENGES FOR THE SUSTAINABILITY OF THE STATE” project "CHALLENGES FOR THE LATVIAN STATE AND SOCIETY AND THE SOLUTIONS IN INTERNATIONAL CONTEXT (INTERFRAME-LV)"

\section{About the} authors

\section{GUDELE INA}

\section{Mg.ing.}

Latvia University of Life Sciences and Technologies

\section{Fields of interests}

E-commerce, public administration, Internet technologies.

\section{Address}

Liela street 2, Jelgava, LV-3001.

Phone: +37127842437 .

E-mail: ina.gudele@gmail.com

\section{JEKABSONE INGA}

Dr.sc.admin., assist.prof.

RISEBA University of Applied Sciences

\section{Fields of interests}

Public administration, citizens' involvement, regional and local development, data analysis, e-commerce.

\section{Address}

Meza street 3, Riga, Latvia, LV-1048.

Phone: +37127116147 .

E-mail: jekabsone_inga@inbox.lv 